\title{
May Their Lineages Live on - an Editorial Board Tribute to Zena Werb and Gil Smith
}

\author{
The Editorial Board, Journal of Mammary Gland Biology and Neoplasia ${ }^{1}$
}

Received: 29 September 2020 / Accepted: 5 October 2020 / Published online: 23 October 2020

(C) Springer Science+Business Media, LLC, part of Springer Nature 2020

Within the short span of just 3 weeks in June and July, 2020, the mammary gland biology community found itself mourning the passing of 2 friends and eminent scientists in the fieldDrs. Zena Werb and Gil Smith. Both Zena and Gil had contributed their entire lifetime to decades of pioneering work studying the normal and neoplastic mammary gland and its biology. In fact, their combined careers amounted to over 100 years - a century - all devoted to studying the basis of how cells communicate, identify and evolve, and function in the mammary gland - both in the normal state and in the progression to cancer.

The legacy that Zena and Gil leave behind goes beyond anything that can be captured in words. Both were prolific scientific authors - a search of Pubmed limited by the term "and mammary" highlights that their combined authorship tally was over 270 peer-reviewed publications when confined by that one keyword. Not only were they prolific, they were also impactful - both of their laboratories consistently published in the highest tier of journals over many years, right up until their passing, and their findings extended to fields far beyond those related to the mammary gland.

Zena and Gil were true friends and colleagues to many within the mammary gland biology community. As mentors they, within their laboratories, gave rise to multiple generations of cell biologists, just like progenitor cells within the mammary gland would. Many of those trainees are now leaders within the field and have gone on to give rise to their own lineages. At the same time, both Gil and Zena became part of a local niche in the mammary gland and developmental biology communities at their institutions; both were known for their enthusiasm to collaborate and to foster ideas within

The Editorial Board, Journal of Mammary Gland Biology and Neoplasia

rchovey@ucdavis.edu

1 Department of Animal Science, University of California, Davis, 2145 Meyer Hall, One Shields Avenue, Davis, CA 95616-8521, USA their local microenvironment. They were widely-respected legends within their respective institutions of the University of California, San Francisco, and the National Institutes of Health, and across their local regions. Yet the ideas they consistently seeded also spread so much further afield across the globe, just like how the mammary epithelium expands into the gland. Both were cherished attendees and presenters at meetings including the Gordon Research Conference on Mammary Gland Biology, which has recently granted the opportunity to recognize Zena and Gil's contributions in a joint tribute session for the 50th anniversary meeting in 2021.

In retrospect, Zena and Gil's work co-evolved over decades, and tracked alongside each other, almost like basal and luminal cells might. The resulting signals they discovered gave cues and guidance for how we all now study the gland. As a case in point, both scientists changed the way we now look at the interaction of epithelial cells with each other $[1,2]$ at different stages of development, as well as the surrounding microenvironment $[3,4]$. Both incorporated and assessed the importance of the endocrine and paracrine environment $[5,6]$. And both developed, used and shared technologies to study the mammary gland in clever ways - particularly through the use of transplantation and cell labeling [7, 8]. Many Board members were fortunate enough to have trained with, to have learned techniques from, or to have collaborated with, Zena and/or Gil over their careers - and there is no doubt their legacy will live on. Following are some of the many tributes from our Editorial Board members:

Zena was a long time colleague and friend and will be sorely missed. Our laboratories often worked in parallel studying mammary gland development and breast cancer. Zena's laboratory set the standard for innovative research in the field. Several of our trainees went to Zena's laboratory and she sent one of hers to BCM. We would often see each other at yearly Mammary Gland GRC and AACR meetings. My deepest condolences to her family 
in Canada. - Jeffrey Rosen C.C. Bell Professor and Vice Chair of Molecular \& Cellular Biology, Baylor College of Medicine, Texas, USA.

I was very excited to first meet Zena when she visited ICR. I knew her scientific opus and that I was lucky to have the opportunity to discuss my research with her. Despite her packed schedule, she was fully engaged and happy to scrutinise and discuss even the most mundane aspects of my results and share her insights. To my surprise, she seemed genuinely disappointed when it was time to take her to her next appointment which was a break for lunch. You could tell she lived and breathed for the opportunity to learn anything new in case there might be a hidden scientific nugget for her to find. - Bea Howard, The Institute of Cancer Research, London, UK.

Zena was not only an innovator in the development and cancer fields but also was an important mentor to many. She offered career and scientific advice with care and honesty, and provided unwavering support for women in science. Because of pioneers like her, I have always felt supported in pursuing my career. Her robust enthusiasm for science, mentoring, travel, and cooking will always be fondly remembered! - Alana Welm, The University of Utah, Utah, USA.

Gil and I were very close. We worked together from March 1992 to November 1997, during my post-doc at NIH. I could write several pages of anecdotes. We discussed everything: papers, feminism, racism, couplehood, children, divorce, molecular biology, stem cells, the niche, music, talk-shows and a very long lists of etcs... We had so much fun and so many arguments during those years. We also had so much respect for each other in spite all the jokes, teasing and debates we shared. He was a great mentor. I owe him so much! We kept in touch during all these years. Four years ago I visited his lab for a whole month, and he was able, once again, to see what I had not seen in my own results and to re-direct my perspective about my own project. I will miss him. I miss him already. - Edith Kordon, University of Buenos Aires, Buenos Aires, Argentina.

I have numerous great memories of Gil who I met in 99 at the GRC at New England College. He was my inspiration to investigate human breast stem cells with my mentor Chris Potten. Ironically they both succumbed to pancreatic cancer in untimely fashion. Gil was my keynote speaker when I chaired the GRC and it was apt that it was in the year that Jane and Connie published on transplantable mammary stem cells, very much following on from his pioneering transplantation studies. He also loved to talk about English soccer with me and often emailed me during matches when my team West Ham were playing. Gil, I will raise my glass to you, to friendship and to your scientific legacy. RIP. - Rob Clarke, University of Manchester, Manchester, UK.

This is very sad news. Gil's sharp intellect, honesty and dry sense of humour are irreplaceable. He will be very sadly missed by all. He dramatically improved every paper he reviewed, and kept us all on our toes. I am very grateful to have had the opportunity to write a review with him and glimpse his wonderful mind. - Jane Visvader, Walter and Eliza Hall Institute of Medical Research, Melbourne, Australia.

Thanks to the brilliant idea and ongoing efforts of Mohamed Bentires-Alj, "Conversations with key figures in mammary gland biology and breast cancer" are in place to further carry on their legacy through discussions about their personal and research career histories, and their seminal findings. These form part of a greater collection of interviews with key figures in the field that can be accessed at https://enbdc.org/interviews/.

Gil's ideas and enthusiasm for research are immortalized in an interview conducted by Rob Clarke and Mohamed BentiresAlj on March 5th, 2013. Here, Gil recounts his entry into the world of biological research, the early events and factors that formed his career, as well as about his supervisors, collaborators, and peers in those early years. Gil talks about the major biological questions he sought to answer and how his main research tool changed from the electron microscope to mouse models. He passionately discusses cell plasticity, the concept of mammary stem cells and cancer stem cells, and provides his own definition of the mammary stem cell niche. And he addresses the major question left in mammary gland biology according to Gil... watch the interview to learn more!

Part 1: https://www.youtube.com/watch?time_continue= $36 \& v=B 0-813$ geisQ \&feature $=e m b \_l o g o$

Part 2: https://www.youtube.com/watch?time_continue= $6 \& v=q v 3 s-S \_S 7 Y c \&$ feature $=e m b \_l o g o$

"The thing that was most appealing to me about being a research scientist was the fact that I could do as I wished to do, and without outside interference. And I could study and could ask questions that I was responsible for. And I think that it's important for a scientist to understand that is the best gift of being a scientist." - Gil Smith. 
"Keep an open mind. Never completely disbelieve or reject an experiment/experimental result whether it's yours or one of your colleagues or someone you don't care about and never fully accept a positive result, that's positive in your mind. You should be somewhere in between. You should never be all the way convinced or all the way not convinced. That is very important, I think. And if possible, ask the difficult questions. Do not let other people persuade you to give up your ideas. Stick with your ideas. And defend them. And block out this other noise and keep focused." - Gil Smith.

Zena Werb was interviewed on April 5th, 2013 by Mohamed Bentires-Alj. Here, Zena talks about her personal history, how and why her family moved from Europe to America, her upbringing in an "unusual" farming family, and the main career choices she considered. She further reveals the major struggles she faced as a young female scientist and how those issues shaped her career. Zena reminisces about how her interests evolved from biophysics and crystallography to biology, and how she encountered the topic of metalloproteinases that led her to the field of mammary gland biology and studying the role of the microenvironment in regulation of cell behavior and fate. She contemplates questions in the mammary gland field and provides her opinion on the most important questions. Zena also shares her mentoring philosophy, talking lovingly about her "scientific children", and points out the essential qualities of a good scientist, all of which can be seen at the following sites:

Part 1: https://www.youtube.com/watch?v= PyoNKcmtMIw\&feature $=$ emb_logo

Part 2: https://www.youtube.com/watch?v= 05EpOwm70rE\&feature $=$ emb_logo
"We make decisions for lots of reasons. Sometimes they are for negative reasons. But that doesn't mean that the outcome isn't the right one."' Zena Werb.

"Going into things because they are popular usually is very short term... Being passionate about what you are doing, even if no one else is interested, but you think that this is a very important question, and it often becomes that."- Zena Werb.

\section{References}

1. Ewald AJ, Brenot A, Duong M, Chan BS, Werb Z. Collective epithelial migration and cell rearrangements drive mammary branching morphogenesis. Dev Cell. 2008;14(4):570-81.

2. Kordon EC, Smith GH. An entire functional mammary gland may comprise the progeny from a single cell. Development 1998. 1998; 125:1921-30.

3. Coussens LM, Werb Z. Inflammation and cancer. Nature. 2002;420(6917):860-7.

4. Boulanger CA, Mack DL, Booth BW, Smith GH. Interaction with the mammary microenvironment redirects spermatogenic cell fate in vivo. Proc Natl Acad Sci USA. 2007;104(10):3871-6.

5. Egeblad M, Nakasone ES, Werb Z. Tumors as organs: complex tissues that interface with the entire organism. Dev Cell. 2010;18(6):884-901.

6. Wagner KU, Boulanger CA, Henry MD, Sgagias M, Hennighausen L, Smith GH. An adjunct mammary epithelial cell population in parous females: its role in functional adaptation and tissue renewal. Development. 2002;129:1377-86.

7. Welm BE, Dijkgraaf GJP, Bledau AS, Welm AL, Werb Z. Lentiviral transduction of mammary stem cells for analysis of gene function during development and cancer. Cell Stem Cell. 2008;2(1):90-102.

8. Smith GH, Medina D. Re-evaluation of mammary stem cell biology based on in vivo transplantation. Breast Cancer Res. 2008;10(1): 203-8.

Publisher's Note Springer Nature remains neutral with regard to jurisdictional claims in published maps and institutional affiliations. 